Article

\title{
Transnational Civic Education and Emergent Bilinguals in a Dual Language Setting
}

\author{
Marialuisa Di Stefano ${ }^{1, *}$ and Steven P. Camicia ${ }^{2}$ \\ 1 Department of Teacher Education and Curriculum Studies, University of Massachusetts-Amherst, \\ Amherst, MA 01003, USA \\ 2 School of Teacher Education and Leadership, Utah State University, Logan, UT 84322, USA; \\ steven.camicia@usu.edu \\ * Correspondence: marialuisadi@umass.edu
}

Received: 8 June 2018; Accepted: 21 August 2018; Published: 23 August 2018

\begin{abstract}
Inclusion is a fundamental aspect of social studies education in general and democratic education in particular. Inclusion is especially important when we consider the possibilities for transnational civic culture and education. The theoretical framework of this study is based upon concepts of positionality, identity, and belonging as they are related to student understanding of communities. A dual-language, third-grade classroom provided the site for this ethnographic study. Data included participant observations, interviews with the teacher and students, and artifacts of student work. Findings illustrate how the students in the study understood the complexity of their identities at a young age and how the teacher used culturally sustaining pedagogy to foster a third space where this understanding was encouraged.
\end{abstract}

Keywords: emergent bilinguals; social studies curriculum; identity; language; belonging; culturally sustaining pedagogies

\section{Introduction}

The recent increase in isolationist and nationalistic discourses has emphasized the need to understand transnational culture and education. Social studies and language instruction can be sites where this understanding can be fostered, but in their recent meta-analysis of articles reporting on social studies instruction for English language learners (ELs), Yoder, Kibler, and van Hover [1] note that "a small corpus of recent studies has emerged at the intersection between the fields of social studies instruction and second language acquisition" (p. 33). Our article adds to this literature by reporting on the first author's [2] ten-week ethnographic study of a dual language immersion (DLI) third-grade classroom in the northeastern United States. The purpose of the research was to promote a better understanding of the processes and products of identity development in a DLI setting within the context of social studies education. Community and belonging have always been central to social studies education. Whether this sense of belonging is understood through individual experiences, geography, history, or civics, the theme of social studies curriculum revolves around understanding ourselves and our communities better. This theme can be explored through scales ranging from the local to the global to the glocal [3].

The migration of humans and ideas challenge traditional notions of social studies education, and specifically, civic education. In our examination of a third grade DLI classroom, we place belonging and a socially just conception of citizenship as a lens to better understand social studies education. Kymlicka [4] writes: 
A central task of citizenship education is to replace older exclusionary ideas of nationhood with a more inclusive or multicultural conception of citizenship, which challenges inherited hierarchies of belonging and insists that society belongs to all its members, minority as much as majority. All members have the right to shape society's future without having to deny or hide their identities. In this view, permanently settled immigrants are not "guests," "visitors," or "foreigners"; they are "members" of the society and "citizens" like all other citizens. (p. xix)

Belonging, identity, and positionality are central to different types and scales of communities. Due to these variations, belonging, identity, and positionality are relational to heritage, geopolitical belonging, and power relations as they function in communities. Students' senses of belonging and language practices were considered the two main contributors toward the fluidity and hybridity of identity. The theoretical framework of our study was based upon principles of culturally sustaining pedagogy [5] and transnational civic education [6]. These provided lenses for understanding within-group cultural practices and common cross-ground cultural practices in a DLI class in the context of social studies education while examining their contribution to the development of students' identities.

\section{Research Problem}

Speakers of languages other than English in the U.S. educational system have experienced labels that function to marginalize these speakers. Labels include: Limited English Speaking Ability (LESA), Limited English Proficient students (LEP), English Language Learners (ELLs), and English Learners (ELs). These labels are based on a deficit-oriented approach, interpreting cultural and racial difference as a deficiency [7]. In this way, the identities of speakers of languages other than English are marginalized in transitional programs, and the resulting perspective of all students is that being an English speaker is the norm in which all other language speakers are measured. We argue that transitional programs deprive students who speak languages different from English in their homes of a significant part of their identity. Social studies education is diminished for all students because the curricular perspective is narrow and discriminatory when marginalized identities are excluded from the curriculum in subjects such as history and discussions of current events (see References [8-13]). A view of subject areas, such as civics, geography, and history, is distorted when dominant identities function to perpetuate social injustices through the exclusion of marginalized identities.

When the variety of perspectives of individuals and groups that belong to democratic communities are increased in decision making, the legitimacy of the community is increased. This increase of perspectives in social studies education functions to strengthen the democratic mission of public schools by increasing inclusion [3]. DLI programs have often worked against a deficit-oriented approach by increasing perspectives and promoting English language acquisition while sustaining students' first language development. DLI programs in the U.S. have grown exponentially in recent years [14-16]. These programs provide content instruction in two languages [17] and promote academic achievement, bilingualism, biculturalism, and cross-cultural relationships for all students $[18,19]$. For these reasons, there is a need to increase research on the DLI programs in relation to social studies education. This is especially important in early grades where there is a lack of research in the area of social studies generally. There is a need to explore the expression of students' identities along with the resulting understanding of types and scales of communities and cultures within the social studies curriculum.

In the last two decades, multiple studies have examined identity development and equity within DLI classes [20-27]. These studies illustrate how dual language learners from different races and ethnicities often suffer the consequences of an unequal distribution of power and resources, which places them at a disadvantage in DLI programs. This occurred within the stated objectives of such programs that such arrangements would close the opportunity and achievement gap while promoting inclusion. Unfortunately, in the context of dominant economic and governmental structures, middle-class and White communities are in power and thus determine the development of bilingual DLI programs [28]. This points to the complex issues of power that need to be scrutinized in DLI 
settings [29]. If DLI programs intend to be an opportunity to grant more equity of access to education for Latinx and language-minority students, educators need to consider power relations in the classroom as well as in society [29].

The research on educating emergent bilingual students is extensive and wide reaching; to consult some of the latest work that discusses emergent bilingual education, see References [30-34]. Through different approaches, this corpus of research studies confirms that dual language learners and immigrant students are resilient, optimistic, and cooperative learners [35]. To support emergent bilinguals, close the opportunity gap, and consequently, the achievement gap in U.S. public schools, it is essential to promote research in this area.

The current study focuses on how the development of a DLI program in a predominantly Latinx community acted as a resource to empower students, give them more equitable access to educational resources, and provide a curriculum that is more culturally sustaining and democratic. Culturally sustaining pedagogy [36] attempts to expand a culturally relevant pedagogy lens [37] by incorporating students' multiple identities, cultures, and perspectives [38]. With a culturally sustaining pedagogy perspective in mind, we focus on the development of cross-cultural competences among the students in the DLI class that participated in the study. We advocate for the expansion of cross-cultural competences through which students can recognize their fluid and hybrid identities. This serves as a bridge for social studies education that increases students' sense of belonging, language practices, and understanding of communities. We argue DLI goals can be achieved through the consideration of situated knowledge [39] in a learning environment that: (a) encourages the development of a socially constructed idea of citizenship in terms of belonging [40]; and (b) presents language as a practice [41] and facilitates the development of imagined communities [42]. Recognizing hybrid identities means to legitimate them, give voice to marginalized groups in our society, empower students, and grant more equitable access to educational resources.

For these reasons, the two-way DLI setting in this study seemed the ideal context to address the following research questions:

1. How do students understand their sense of belonging and their language practices?

2. How does this understanding influence knowledge of transnationalism, identities, and communities?

\section{Theoretical Framework}

The overarching themes that guide our conceptual framework are: (a) transnational civic education, (b) fluid hybrid identity as both the origin and result of culturally sustaining pedagogy, (c) sense of belonging and the translanguaging practices as two main aspects that contribute to development of identity, and (d) culturally sustaining pedagogy as the outcome of within-group cultural practices and common cross-ground cultural practices. This aligns with the framework presented by Jaffee [43]. Hence, the study is located within the corpus of scholarship dedicated to extending the education of historically marginalized youth. We chose to frame our study with one of multiple counter-hegemonic approaches to the U.S. education system $[5,36,38,44,45]$, which is an attempt to question and dismantle hegemonic power through the analysis of identity development in a DLI program and implications for social studies education.

The concept of belonging and community are central to civic education. However, traditional notions of citizenship as tied to the nation state are under increased scrutiny in light of global inequalities and the organization of "truth". We use the concept of transnational civic education to better understand how a counter-hegemonic social studies curriculum might function in tandem with identities, positionalities, and communities. Bashir [6] describes transnational civic education as: 
Constitutively transformative and critical in its orientation. Transnational civic education not only embraces and promotes multiple identifications and belonging to regional and global dimensions but also requires critical pedagogy [46,47] that profoundly rethinks and reforms the dominant national curricula. Besides endowing citizens with critical and investigative tools, these reformed curricula demonstrate a sensitivity to the particularities and histories of various groups through exposing citizens to the richness of cultural and religious interconnectedness and diversities of a region. (pp. 32-33)

This view of civic education places an ethics of recognition as central to socially just education. It is a recognition that each individual has multiple and overlapping identities that are embedded in a network of power relations [3]. Traditional notions of citizenship are exclusionary because they are built upon narrow epistemological stances about communities, their members, and relationships. Vickery [48] writes, "While citizenship is a legal status that gives citizens certain rights and privileges, it also becomes a social construct and discursive practice that has changed over time to exclude certain bodies from belonging and participating as legitimate members of the body politic" (p. 29). Her study of three African American women social studies teachers illustrates the ways that conceptualizations of citizenship can be more inclusive. She found that the participants in her study emphasized senses of belonging, ways to care about community, and cultural identities as central to conceptualizations of citizenship.

We understand identity as a hybrid construction of personal and social meanings attributed to individual and social life. Identity expounds on the meanings attributed to the singular events that occur in someone's life and socio-historical circumstances and evolutions in one's capacity of interpretation. Drawing upon a well-established collection of identity studies [49-58], Lee and Anderson [59] assert "identity is a fluid, socially constituted achievement that is constructed across micro-social (individual) and macro-social (cultural/institutional) timescales" (p. 185). In this sense, identity is a hybrid construction of individual and social life events in a constant becoming, which depends on a specific understanding of them. Consequently, the process through which children comprehend who they are and what communities they belong to is in constant change and is determined by various experiences.

Engaging in the fundamental considerations presented by Paris and Alim [36,45] related to culturally sustaining pedagogy, we acknowledge that dual language learners' identities can manifest under multiple forms. For this reason, we elected to focus specifically on the aspects of belonging and languages and the ways that these interacted with social studies education. The significance of belonging and languages is something the first author became familiar with during her personal and professional experience as an immigrant language learner and teacher in the U.S. Following Paris and Alim's [36] perspective, she strives to extend the culturally relevant pedagogy paradigm to the sustaining phase $[5,60,61]$. Discussing culturally relevant rather than sustaining pedagogy is insufficient for the present historical moment [62]. Particularly during an anti-immigration era, hyperintensified with the 2016 U.S. presidential campaign and aftermath, there is the need to sustain cultural pluralism in schools and not merely to make it visible or relevant.

We situated this research upon the principles of culturally sustaining pedagogy because, along with Paris and Alim [36] and Ladson-Billings [38], we share the need to push the boundaries of culturally relevant pedagogy to respond to the increasingly diverse demographics and social changes of public schools in the U.S. The "children of immigrants represent all of the growth in the K-12 population nationally" [35] (n.p.). These students require the opportunity to cultivate their language and culture, and to elaborate a sense of place and belonging between geographical and imaginary borders. In this way, dual language learners can become bridge builders of transnational civic culture to promote more inclusive learning environments and society. It is in these settings that dual language learners translanguage in a third space [63] that is hybrid and makes sense of a multilingual settings in the context of language use. García [64] writes that "Translanguaging is the act performed by bilinguals of assessing different linguistic features or various modes of what are described as autonomous 
languages, in order to maximize communicative potential" (p. 140). This approach challenges dominant understandings of monolingualism and bilingualism as ossified and unresponsive to the complexity of third spaces of multilingualism.

Finally, the narratives of students and teachers are a central component of culturally sustaining and social justice oriented pedagogy. Solórzano and Yosso [65] write, "A majoritarian story distorts and silences the experiences of people of color" (p. 29). For example, in their work to create more inclusive history curriculum for prospective teachers and fourth grade students, Salinas, Rodríguez, and Lewis [66] observed that "while a quick scan of the official state curriculum standards document may yield a list of Spanish surnames, the historical figures and events are clearly European" (p. 178). In their project they created inquiry questions that lead students to better understand marginalized voices in history. Student artifacts such as "Tejana/o Journey Boxes, Tejana/o Story Box Biographies, and Tejana/o History Trifolds" (p. 186) helped students deconstruct dominant narratives found in history standards and textbooks.

Scholars point to the need for curriculum and pedagogy to include the perspectives of Latinx students, teachers, and their epistemological stances. This inclusion can take the form of counter narratives and should be included in all educational settings ranging from early childhood to higher education [67-69]. Fránquiz, Carmen Salazar, and Passos DeNicolo [70] discuss the importance of creating activities in the curriculum that challenge monocultural understandings. For example, students of color in their teacher education courses brought artifacts from their experiences that connect with a theme or narrative of their past. Fránquiz et al. write that students "learned in their training that the funds of knowledge from home were as important as the valued language and literacy practices at school" (p. 288). Learning activities that emphasize counterstorying or counter-narratives create an environment where all students are able to challenge deficit models and dominant narratives that often dominate the curriculum. This aligns with borderlands theory as described by Anzaldúa [71]. The borderland serves as a third space for a critical democratic education [72] and transnational civic education [6]. In her study of adolescent Latinas' identities, Bondy [73] found that, "adolescent Latinas challenge both dominant discourses on Latina/o immigration and nationalist conceptions of citizenship. Their notion of rights extends beyond citizens who live within one nation-state" (p. 234). The culturally sustaining curriculum and pedagogy in the setting of our study provides an illustration how this might be accomplished in an elementary school.

\section{Research Design and Procedure}

Theoretical or purposeful sampling [74] guided efforts to select the school in which the study was conducted. A two-way DLI school environment offered the ideal setting to explore how young students work on their sense of identity, belonging, and language practices. South Whaterbridge Community School is a Title 1, K-8 public school located in an urbanized landscape, in the vicinity of a metropolitan city in the northeast of the United States. This school had a predominantly Latinx population and followed the Camaradas two-way 50/50 DLI model (an adaptation of the Gómez and Gómez model) [75,76]. In this instructional model, students attend classes in Spanish every other week. Students learn math and literacy in the language of the week, though Art, Health, Music, and P.E. are always taught in English regardless of the week's language. During the fall semester (August-December), science is taught in Spanish while social studies is conducted in English; students with this arrangement switch in spring semester.

An ethnographic methodology [77] seemed most appropriate because it allowed participant observations of a predominantly Latinx EL student population learning content via Spanish instruction. The Spanish teacher who participated in the study, Ms. Ramírez (pseudonym), was a participant but at the same time an essential liaison between the ethnographer and student participants. Ms. Ramírez teaches two cohorts of 21 students, alternating on a weekly basis between the red and the blue groups. Ms. Ramírez only instructs in Spanish while her partner teacher instructs only in English, alternating two cohorts of students. During the fall semester (when this study occurred) social studies was taught 
in English by Ms. Ramírez's partner teacher and reinforced in Spanish by Ms. Ramírez. This study occurred in Ms. Ramírez's Spanish class, including participant observations of both students' cohorts.

Data were collected in the form of field notes from participant observations, informal interviews in the field, teacher and student semi-structured interviews, and the student homework and artifacts over a 10-week period (30 school days, one PT conference event, and one final project presentation at the end of the school year). All interviews and part of the field notes were audio recorded. More details will be provided below regarding the interview protocols developed for the teacher's and students' semi-structured interviews.

The study was conducted on Tuesdays, Wednesdays, and Thursdays of each of the 10 weeks. We purposefully avoided Mondays and Fridays because on those week days the school was often in session for only half a day (e.g., holidays, long weekend, and other scheduled events). Our intent was to observe the teacher and the students while acting in their regular school environment and schedule. In addition, this gave continuity to Ms. Ramírez's schedule, who was informed about the ethnographer's presence on those days.

Before engaging in the study, the first author visited schools with similar dual language programs in the area and created a list of characteristics that were common with the school program coordinator and teachers. The first author also volunteered in the school, met with other teachers from the same school, and met with representatives of the parents' association. Embracing "ethnography as engaged listening" [78], these activities helped to prepare the ground and to reflect on this ethnographic work as the "participation in, and engagement with, the lives of our fellow human beings" [78] (p. 569) as we interacted in the classroom for 10 weeks.

The first author collected 20 teacher's interviews (approximately $5 \mathrm{~h}$ ). These interviews were conducted both in English and Spanish. The teacher primarily used Spanish when referring to the cultural elements she integrated into the classroom instruction. At the same time, she often used English while discussing the DLI curriculum and requirements as mandated by the State Department of Education. The first author followed the teacher's discourse and conducted interviews in a way she demonstrated to be most comfortable. In these interviews, I asked the teacher to describe the lesson plans she crafted for the week and the activities related to the social studies curriculum, the use of language, and reference to the acquisition of special elements into the students' daily routine. I also asked the teacher to comment on student participation in the planned lessons and activities (e.g., if she believed students achieved the learning objectives, how their use of languages and their references to their sense of belonging were connected to the classroom curriculum, etc.).

In addition, the first author conducted semi-structured interviews with 38 students. In order not to interfere with classroom daily activities, students were conveniently selected each day for a few minutes of interview (total of approximately $4 \mathrm{~h}$ ) concerning the classroom activities they had completed, which targeted identity development. The first author always opened interviews in Spanish to respect the class language of instruction. Students were allowed to switch between English and Spanish, and to translanguage any time they wanted, in order to maintain a positive, encouraging, and third space environment. An interview protocol was developed for the students' interviews and was articulated around questions related to the activities on which the students were currently working or episodes related to family memories and traditions (e.g., what did you draw here? Why? How come? What did you write here? Why? How come? What is your favorite food? Why? What do you like doing during your free time? What is your favorite game? Would you like to tell me about you last trip with your family? How do you usually celebrate holidays? Where would you like to go on vacation?)

Finally, the first author took field notes of participant observation and collected student homework and artifacts, which were assembled and responded to the students' elaborations of places of belonging and language practices. These artifacts typically correspond to two main categories: iconic artifacts (children's drawings, writing webs, and Venn diagrams), and literacy artifacts (journal logs and test work sheets) [79]. After completion of the study, the first author asked the second author to coauthor this article. 


\subsection{Analysis of Data}

A combination of deductive and inductive thematic analysis ensured a rigorous data analysis process [80]. Deductive thematic analysis proceeded mainly from the research questions and theoretical framework. An a priori template of codes was developed [81] to initiate data analysis. Inductive thematic analysis advances from the raw data, and for this reason, it is also called a data-driven method. This method is based on the development of meaningful codes: "A good thematic code is one that captures the qualitative richness of the phenomenon" [82] (p. 31). This method of analysis captured not only anticipated themes in the study based upon the conceptual framework and the deductive analysis, but also those unexpected results that emerged through the qualitative richness of the DLI setting.

The first cycle of coding proceeded primarily from the initial research questions and theoretical framework to develop a template of a priori codes. For the second cycle, inductive thematic analysis was used. Proceeding from the raw data, verbal and visual patterns were developed for appropriate additional codes [82]. The coded segments were grouped into categories. Early data analysis was conducted while in the field, using the memoing function of Maxqda 12 software data management package for qualitative and mixed methods research, developed by VERBI GmbH based in Berlin, Germany. Codes were assigned, developed into correspondent categories, and correlated between categories and codes. Meanings of the most relevant categories and the least recurrent ones were explored in order to portray a complete scenario of the teaching-learning environment in the DLI third-grade classroom that was observed.

\subsection{Our Positionalities}

Identity and positionality are interconnected. As the first author, not only do I identify the essential components of my identity but I interpret them and position myself according to them. I understand my interpretation of identity as a hybrid construction in response to my Western glocalized positionality. I have learned that the languages I speak are not just a vehicle of communication but also carry my cultural identity [53]. I approached this study as a hybrid adult transnational [83] product of the cultures and languages I acquired growing up in Sicily, Italy, studying in the northwest of the United States, and interacting with my Caribbean family and Latin American friends. I understand the social studies curriculum and instruction through the lens of these experiences of my positionality within these different communities.

As the second author, I approach this study as a White, queer, male who only speaks English. These identities, with the exception of queer, were privileged in the social studies curriculum that I grew up with. This privilege worked to create a veil of ignorance where my identities were included in curriculum while nondominant identities were excluded from curriculum. My perspective on different types and scales of communities were narrow and from the perspective of a White male who only speaks English. It is only through my identity as a queer male that I experienced the way that positionality is relational and fluid. While I am more aware of being queer in places such as rural communities, I am less aware of this aspect of my identity in urban areas. My understanding of social studies education has developed into understanding the fluid and relational aspects of perspectives related to history, geography, economics, and civics.

Through our experiences with social studies education and the various communities that we have understood, we approach this study with an understanding that belonging, identity, and positionality are key components of culturally sustaining pedagogy within social studies curriculum and dual language classrooms.

\section{Findings}

The main research questions focused upon the relations between identity, sense of belonging, transnationalism, and language practices. By looking across the processes developed through classroom 
instruction and their relative products of identity formation in the DLI classroom, we documented the three main findings of this study. First, the students' sense of belonging and their practices of languages are connected to identity through multiple cultural qualities (e.g., places, speaking English and Spanish, translanguaging, living in a collective and shared dimension, food, family, music, dance, and skills acquired in a specific heritage group). Second, the processes the teacher used to guide students in reflection on their sense of belonging and language practices are prevalently based on a dialogical approach and adaptation of the core curriculum (e.g., open classroom discussions, guided reading and comprehension activities), the use of picture books, music, and dance practice. Third, the products of these processes emerged through student class participation, their journals, and the stories they narrated in interviews (e.g., spider map, written paragraphs, short stories built upon family memories, etc.). These findings reinforced the potential of DLI programs to offer multiple opportunities to the Latinx students. At the same time these results also identified certain contradictions, issues of power, and equity that demand attention as they intervene in the implementation of such a program in support of ELs, all of which will be investigated further in the following sections.

Findings of this study indicate that students' understanding of their identities developed from their understanding of their sense of belonging and language practices. Moreover, the students' sense of belonging and practice of language were connected to their identity through places, languages, and multiple cultural features that explicitly referred to their collective and shared community dimension. These can include food, family, music, dance, and other skills acquired in a specific heritage group. The data indicated relevant factors that intersect with identity and culturally sustaining pedagogy, such as the teacher as a role model and migration issues. Identity development and culturally sustaining pedagogy practices were mediated by the teacher in her function as a role model for her students. To illustrate these findings, we focused upon three of the most significant data sets, which were related to the writing workshop about identity development, the class discussion about the 2016 presidential election, and the adaptation of the Second Step curriculum to the DLI class. These data sets were illustrative of the themes that were consistent within and across data sets.

\subsection{Identity and Belonging}

In the first case, students were asked to reflect on the elements that characterized their identities. The most prevalent factors were locations of family origins (places that make sense to students) and the languages Spanish and English, and Portuguese in some cases (which are the most practiced languages in their community). The teacher provided a prompt on the board, asking students to reflect on the different components of their identities and list them in their journals. In the excerpts below, we illustrate how three students reacted to the teacher's prompt and showed understanding of their identities. Students' journals have been transcribed as they appear in the original document, including grammatical errors, in order to maintain their original meaning. Accuracy, or lack thereof, with the Spanish text does not prevent its comprehension. However, grammatical and spelling errors have been corrected in the English translation to provide a better sense of the texts.

Before proceeding with the student's artifacts, it is important to clarify the teacher positionality and how identity development and culturally sustaining pedagogy practices are mediated by the teacher in her function as role model for her students. Ms. Ramírez is an experienced elementary teacher, originally from Colombia, who has lived in the U.S. for 25 years. She is a passionate educator committed to teaching language and culture together, as was evident from the interviews and field notes we collected while gathering information at the school. Her bright and positive attitude is an integral part of her teaching style and clearly characterizes her instructional strategy. For example, her way to greet the students at the beginning of the day set up the tone of the classroom. "iAmigos, empezemos el día positivos!/Friends, let's start the day being positive!" (Field note, week 01, p. 2).

Students' artifacts helped us to examine the process that contributes to the development of the sense of membership and belonging on the basis of spoken languages. Latinx students associated the practice of Spanish with their families' countries of origins and transnationality because their families 
speak Spanish and recognize it as the national language. The first student is Kali [all participants were given pseudonyms] (Table 1), whose mother is from El Salvador. Her parents' places of origins and specific food and recipes connected to Central American cuisine were among the elements she identifies as determinant for her identity.

Table 1. Kali's journal 12 October 2016, (Students' artifacts, PDF file 21, journal).

\begin{tabular}{|c|c|}
\hline Spanish & English Translation \\
\hline $\begin{array}{l}\text { 10-13-16 parte de Mi identidad es para cantar y bailar. } \\
\text { Parte de Mi identidad es para yo avla español. Parte } \\
\text { de Mi identidad es que yo tiene los y las mejores } \\
\text { maestras. Parte de Mi identidad es para tener mi } \\
\text { mejores comida es pupusas tamales y sopa. Parte de } \\
\text { mi identidad es mi papa es de aqie [EE.UU.] y mi } \\
\text { mama es de el Salbador. Parte de mi identidad es } \\
\text { para tener Dios! Parte de mi identidad es que mi } \\
\text { mama gusta a ir a el Salbador. }\end{array}$ & $\begin{array}{l}\text { 10-13-16 Part of my identity is that I like singing and } \\
\text { dancing. Part of my identity is that I speak Spanish. } \\
\text { Part of my identity is that I have the best [male and } \\
\text { female] teachers. Part of my identity is that my } \\
\text { favorite food is pupusas, tamales, and sopa. Part of } \\
\text { my identity is that my dad is originally from here } \\
\text { [U.S.] and my mom is from El Salvador. Part of my } \\
\text { identity is I have God. Part of my identity is that my } \\
\text { mom likes traveling to El Salvador. }\end{array}$ \\
\hline
\end{tabular}

After reading her journal, we interviewed the students and asked them to explain, retell, and add more details about what they wrote. Table 2 documents part of the interview we had with Kali. We wanted to know if Kali perceived her hybrid identity and how she would describe it if prompted during the interview.

Table 2. Kali's interview, 26 October 2016 (Students' interview, Audio file 08).

\begin{tabular}{|c|c|}
\hline Spanish & English Translation \\
\hline $\begin{array}{l}\text { Interviewer: Kali, ¿quieres agarrar tu cuaderno y } \\
\text { explicarme lo que escribiste? }\end{array}$ & $\begin{array}{l}\text { Interviewer: Kali, do you want to grab your notebook } \\
\text { and explain to me what you wrote? }\end{array}$ \\
\hline $\begin{array}{l}\text { Kali: "Para mí, mi identidad es que me gustan todas } \\
\text { las maestras. Y me gusta cantar en mi casa. } \\
\text { Mi identidad es para hablar español e inglés. Y me } \\
\text { gusta El Salvador. Yo me amo a mi familia. Me gusta } \\
\text { a bailar salsa. Yo soy bilingüe. Me gusta hablar inglés } \\
\text { y español, en la casa y en la escuela. Yo habla más } \\
\text { ingles en mi casa, y poquito español. Mi talento es } \\
\text { para cantar, bailar, y dibujar. Yo amo a } \\
\text { mis hermanos". }\end{array}$ & $\begin{array}{l}\text { Kali: "For me, my identity is that I like all the } \\
\text { teachers. And I like to sing in my house. My identity } \\
\text { is to speak Spanish and English. And I like El } \\
\text { Salvador. I love my family. I like to dance salsa. I am } \\
\text { bilingual. I like to speak English and Spanish, at } \\
\text { home and at school. I speak more English in my } \\
\text { house, and a little Spanish. My talent is to sing, dance, } \\
\text { and draw. I love my brothers". }\end{array}$ \\
\hline $\begin{array}{l}\text { Interviewer: Que interesante. Y dime ¿qué te gustas } \\
\text { más de la cultura, por ejemplo de la cultura de aquí? }\end{array}$ & $\begin{array}{l}\text { Interviewer: How interesting! And tell me, what do } \\
\text { you like most about culture, for example the culture } \\
\text { here? }\end{array}$ \\
\hline Kali: ¿Qué es un cultura? & Kali: What is a culture? \\
\hline $\begin{array}{l}\text { Interviewer: Cultura es muchas cosas, es la comida, el } \\
\text { baile, como nos vestimos, la música que nos gusta, } \\
\text { todo es parte de la cultura que tenemos. }\end{array}$ & $\begin{array}{l}\text { Interviewer: Culture is many things, it's the food, the } \\
\text { dance, how we dress, the music we like, everything is } \\
\text { part of the culture we have. }\end{array}$ \\
\hline $\begin{array}{l}\text { Kali: A mí es que me gusta bailar en mi casa mucho, } \\
\text { porqué yo tengo algo para bailar YouTube en mi tele. } \\
\text { Me gusta poner camisas así de mangas cortas. Me } \\
\text { gusta comer macaroni and cheese, spaghetti meat balls, } \\
\text { frutas, un poquito de vegetales, porque a mí no me } \\
\text { gusta vegetale mucho. Mi mamá es del Salvador y mi } \\
\text { papá de aquí. Tengo un poco de los dos, un podo de } \\
\text { todos, y más. }\end{array}$ & $\begin{array}{l}\text { Kali: I like dancing at home a lot, because I have } \\
\text { something [a device] to dance [to stream] YouTube on } \\
\text { my TV. I like to wear shirts with short sleeves. I like to } \\
\text { eat macaroni and cheese, spaghetti meat balls, fruits, } \\
\text { a little vegetable, because I do not like vegetable a lot. } \\
\text { My mom is from El Salvador and my dad from here. I } \\
\text { have a bit of both, a bit of all, and more. }\end{array}$ \\
\hline
\end{tabular}

The second student is Ariel (Table 3), whose parents are from Brazil. Ariel indicated that his musical passion, his talent with the cello (that he practices at South Whaterbridge Community School), 
and his parents' country of origin define who he is. Like the other students, Ariel followed the prompt "part of my identity is ... " The reiteration of the prompt served both language acquisition (i.e., getting familiar with the subject-verb-object structure which apply to both Spanish and English language) and subject matter purposes, illustrating how students' identities are determined by the coexistence of multiple elements.

Table 3. Kali's journal 12 October 2016, (Students' artifacts, PDF file 21, journal).

\begin{tabular}{|c|c|}
\hline Spanish & English Translation \\
\hline $10 / 12 / 16$ mi identidad & $10 / 12 / 16$ my identity \\
\hline $\begin{array}{l}\text { prate de mi identidad es que mi mamá nasio en } \\
\text { brazil. parte de mi identidad es que mi papá nasio en } \\
\text { brazil. prate de mi identidad es que yo gusta toca el } \\
\text { cello. prate de mi identidad es que yo quedo toca el } \\
\text { torpeta. Tambine quedo toca el tabor. yambién yo es } \\
\text { un studet South Whaterbridge Community School. }\end{array}$ & $\begin{array}{l}\text { Part of my identity is that my mom was born in Brazil. } \\
\text { Part of my identity is that my dad was born in Brazil. } \\
\text { Part of my identity is that I like playing the cello. Part } \\
\text { of my identity is that I would like to play the trumpet. } \\
\text { I would like to play the drum as well. Also, I am a } \\
\text { student at South Whaterbridge Community School. }\end{array}$ \\
\hline
\end{tabular}

In the third example, we document Sylvia's response to the writing workshop (Table 4). Sylvia's parents are both White U.S. citizens from European (i.e., Italian, Greek, and Scandinavian) and Middle Eastern origins (i.e., Arabic). Nevertheless, Sylvia underlined that she sees herself as a bilingual person, because of her ability to speak English and Spanish in her school context. At the same time, she embodied all the other linguistic (i.e., "I know/speak six languages") and ethnical (i.e., "I am Italian, I am a Viking") characteristics she inherited from her parents.

Table 4. Sylvia's journal on identity. (Students' artifacts, PDF file 25).

\begin{tabular}{|c|c|}
\hline Spanish & English Translation \\
\hline $\begin{array}{l}\text { yo es Bilingüe, yo suy italeano, yo suy una vicing, yo } \\
\text { suy Gresia, yo es } 9 \text { años, yo sabe } 6 \text { [lenguas], legusta } \\
\text { Bilar, saves Español, saves etaleano, saves Igles, saves } \\
\text { gresia, legusta cantar, yo legusta cabir, yo legusta } \\
\text { Bilar, yo legusta leer. Partes de mi Identidar es mi } \\
\text { mamá es Gresia. Mi papá es etaliano, árabe y vicihgo. } \\
\text { Yo es Gresya, etaliano, arabe y vicingo. Yo Legusta } \\
\text { Bilar, Leer y cantar. Yo Saves Español, etaliano, } \\
\text { inggles y Gres. Mi escwela es South Whaterbridge } \\
\text { Community School. }\end{array}$ & $\begin{array}{l}\text { I am bilingual, I am Italian, I am a Viking, I am from } \\
\text { Greece, I am } 9 \text { years old, I know /speak six } \\
\text { [languages], I like dancing, I speak Spanish, I speak } \\
\text { Italian, I speak Greek, I like singing, I like learning, I } \\
\text { like dancing, I like reading. Part of my identity is that } \\
\text { my mom is from Greece and my dad is Italian, } \\
\text { Arabic, and Viking. I am Greek, Italian, Arabic, and } \\
\text { Viking. I like dancing, reading, and singing. My } \\
\text { school is South Whaterbridge Community School. }\end{array}$ \\
\hline
\end{tabular}

Students largely recognized the importance of learning English in the U.S. However, as the above sample documents, all third-graders involved in this study did not view English as an exclusive practice to assert their membership and belonging to their local community. Both English and Spanish, along with Portuguese and other languages in some specific cases, are integrated language practices through which the third-graders understood their sense of belonging and transnational civic identity as multilingual and multicultural individuals.

\subsection{Examining the Political Landscape}

In the second case, students discussed the implications of the election of Donald J. Trump as the 45th president of the United States of America. This study took place in the fall of 2016, during an inflamed and controversial presidential campaign that was built upon a sense of xenophobia and exacerbated isolationism. As part of social studies curriculum, which was delivered only in English during the first semester of the school year, the students had studied the composition of the federal government and the division of power through the three branches of government (executive, legislative, and judicial). 
In the excerpt below (Table 5), we document part of such class discussion as reported in the first author's participant observation and research journal.

Table 5. Class discussion about the 2016 Presidential Election (Field note, week 9, page 3).

\begin{tabular}{|c|c|}
\hline Spanish & English Translation \\
\hline $\begin{array}{l}\text { Ms. Ramírez: ¿Serena, qué piensas tú [acerca del } \\
\text { nuevo presidente]? }\end{array}$ & $\begin{array}{l}\text { Ms. Ramírez: Serena, what do you think [about the } \\
\text { new president]? }\end{array}$ \\
\hline $\begin{array}{l}\text { Serena: Yo pienso que Donald Trump es malo porque } \\
\text { él has estado haciendo cosas malas como si los padres } \\
\text { se van a sus países, los niños se van a ser adoptados. }\end{array}$ & $\begin{array}{l}\text { Serena: I think that Donald Trump is bad because he } \\
\text { has been doing bad things, such as if parents are } \\
\text { deported to their countries, their children will } \\
\text { be adopted. }\end{array}$ \\
\hline $\begin{array}{l}\text { Emma: yo me voy con mi mamá si ella se va, porque } \\
\text { estamos construyendo una casa en El Salvador. }\end{array}$ & $\begin{array}{l}\text { Emma: If my mom will have to leave, I will go with } \\
\text { her because we are building a house in El Salvador. }\end{array}$ \\
\hline Ms. Ramírez: ¿Cassandra, qué opinas tú? & $\begin{array}{l}\text { Ms. Ramírez: Cassandra, what is your opinion } \\
\text { about that? }\end{array}$ \\
\hline $\begin{array}{l}\text { Caassandra: Mi opinión es que es muy malo porque } \\
\text { él dice, como ella (refiriéndose a Emma) dice, que si } \\
\text { alguien no nació aquí [en EE. UU.] necesita ir al país } \\
\text { que nació y por eso no puede estar en esta escuela. }\end{array}$ & $\begin{array}{l}\text { Cassandra: My opinion is that he is very bad because } \\
\text { he says, as she said [referring to Emma], that if } \\
\text { people were not born here, they need to go back to } \\
\text { their countries so they cannot stay in this school. }\end{array}$ \\
\hline $\begin{array}{l}\text { Ms. Ramírez: Yo sé que esta es una noticia muy } \\
\text { fuerte. Yo quiero que cada uno mantenga una } \\
\text { mentalidad positiva. Aunque Donald Trump quiera } \\
\text { pasar una ley necesita que otra gente la apruebe. Sus } \\
\text { padres tienen muchos años aquí [ ... ] Quiero que } \\
\text { estén positivo que les digan a sus papas que su vida } \\
\text { va a seguir común y corriente. }\end{array}$ & $\begin{array}{l}\text { Ms. Ramírez: I know this is a very strong news. I } \\
\text { want everyone to maintain a positive mindset. } \\
\text { Although Donald Trump wants to pass a law, he } \\
\text { needs other people to approve it. Your parents have } \\
\text { been here for many years [...] I want you to be } \\
\text { positive, to tell your parents that their life will } \\
\text { continue exactly as it has been until now. }\end{array}$ \\
\hline
\end{tabular}

Ms. Ramírez is cognizant of her role as educator of children from immigrant families in a DLI setting. She strives to promote empathy among all students in the classroom. She is an immigrant herself and feels the struggle of being between countries. Students were concerned with the new presidential immigration policy, regardless of their individual race or ethnicity (i.e., Serena and Emma are Latinas and children of immigrants, while Cassandra is White and a descendent of U.S. born parents). To reassure students and help them overcome their fears, Ms. Ramírez implicitly alluded to the three branches of the U.S. government, the division of powers, and the institution of the president, Congress, and the Supreme Court, which are part of the third-grade social studies curriculum. Students learned this content about three weeks before the election and took a test in English on this topic at the end of October, during their Spanish class. However, they never addressed the topic of balance of powers in Spanish. The conversation about the presidential election had the potential to empower the students but was developed differently in the English and the Spanish cohort, as the first author recorded in a field note:

It is my understanding that the English cohort had a similar conversation in class on the day after the election. They talked about the results. One of the students mentioned that, regardless the results, nothing bad could happen to them neither to anyone else in the country because the U.S. government is based on three separate branches so the president cannot do whatever he wants without the approval of the other two branches, as they studied in class a couple of weeks ago. The students said that they wrote an entry in their English journals about the presidential election and the connections with the three branches of the government. However, they did not complete a similar activity with their Spanish journal. (Field note week 9, p. 1) 
Because of time constraints, one of the two students' cohorts had to take an English test on the U.S. Constitution during the Spanish class (because students are required to take standardized tests during the same period of time, they take them in English regardless of their week's language of instruction). In the writing prompt, students were asked: "Explain why the U.S. Constitution is an important document. Be sure to include important details in your answer" (Field notes, week 9, p.1). This is Edith's answer as it appeared on her answer sheet; grammatical errors have not been corrected.

The constitusion is important because it is made by the president. Who made the constitution? Obama and the Founding Fathers. Actully all presdient's made the constituton dury the president's of the United States of America. My question is are those kids rich because they meeted president Obama. The constitution is so important for the presidents very mega important. It is mega impotant. For us to evre buddy in the hole intire world not for some pepele. (Edith's U.S. Constitution test answer, Students' artifacts, PDF file 29)

Edith, as many of her classmates, is a U.S. born child from a family that emigrated from Central America. On the front page of her exam, there was a picture of former president Obama, interviewed by children reporters about the most important tenets of the U.S. Constitution. As a result of the interview, the authors placed in bold the three most important facts: (a) "the constitution set up our government;" (b) "it gives people rights," and (c) "we can change it" (Field notes, week 9, p. 1). These three main elements did not align with Edith's response, which instead focused on the involvement of former president Obama with the U.S. Constitution and the presence of children evidently from richer schools in Edith's interpretation, chosen to meet with the president.

We argue that if the English unit about the U.S. Constitution would have been supported by complementary instruction in the Spanish class, students might have been able to build upon this concept with a better understanding of how the Constitution bridges their identities and real-life experiences as children of immigrants in the U.S. Engaging in dynamic models of bilingualism [84-86], students could bridge the content of languages and contexts, developing meaningful connections between their school and home experiences. In this case, the use of translanguaging aligned with this specific task (series of instruction strategies where teachers use translanguaging as scaffold) [86] could have sustained a more holistic understanding of the child as emergent bilinguals and transnational citizens who are directly impacted by the new political landscape.

Supporting the acquisition of social studies content in both English and Spanish at once could promote a richer understanding and prompt a better depth of understanding in the student's response. In addition, it could provide the opportunity to promote a counter-hegemonic social studies curriculum, as envisioned in a transnational civic education perspective. Edith and many of her classmates are transnational citizens, which means that they embody the richness of their multicultural and multilingual glocal society. The risk is that instead of understanding their transnational experience as a plus, these students only perceive it as what differentiates them from those "rich kids" dominating their exam cover page.

What excerpts from Edith's assignment shows is the need to reconsider some aspects of program structure and instructional strategies. Incorporating the presidential election into Spanish language arts activities, such as the journal logs, could have supported the social studies curriculum, acquired in the English class, with the development of related knowledge and vocabulary about how the U.S. government functions in the Spanish class. This would have consolidated understanding and nurtured dual language learners' academic vocabulary, impacting their entire communities and increase perspectives in the social studies. In this sense, the program articulation (i.e., during fall, science is taught in Spanish, while social studies is conducted in English and reinforced in Spanish; the Second Step portion of the social studies curriculum is taught in English and Spanish at the same time) may have limited the students' engagement with a more profound understanding of the interconnections between identities, citizenship, and power. Considerations about the sustainability of this program articulation and the compensation through translanguage scaffolding, as emerged from this results section, will be further explored in the discussion and implication sections. 


\subsection{Transnational Civic Education through the Second Step Curriculum}

The third data set that contributed to exploring and understanding how students' transnational civic identities are partially incorporated in the social studies curriculum is the Second Step curriculum. Second Step is a program implemented in the school district to foster social-emotional learning, prevent bullying, and emphasize child protection [87]. The district required educators to integrate Second Step into the curriculum, teach at least one lesson per week, and reinforce the skills introduced in the lesson throughout the day. The goal is to facilitate students in acquiring problem-solving skills to use at school and home.

Let's imagine that two third graders are fighting over a stuffed animal. They finally find a mutual agreement and decide to share it. This is an example of problem solving steps. In English: name the problem, think about some solutions, consider the consequences (good and bad), and come up with a plan. What was the best choice to pick? It is so important to encourage parents to try to use this set at home with kids. When kids get out of control and get loud, our instinct as parents is to yell back. Instead, the quieter and calmer you keep yourself, the more likely you are that your child will also calm down with you. Second Step is all about learning to deescalate problems, instead of escalating by getting louder, and getting bigger. It is important as the adults that are modeling with the calming down steps for them, which is not always easy. (Field notes, file 06, Second Step meeting, recorded on 4 October 2016)

In this passage, I paraphrased Ms. Ramírez's response in an informal interview, which occurred during teacher preparation time. Second Step targeted the students, their families, and their communities at the same time. The curriculum could be adapted to the transnational experiences of students. The intent was to communicate problem-solving skills that can benefit individuals in de-escalating controversies and reaching a win-win situation.

Second Step included 22 lesson plans, a teacher textbook, and multiple explanatory cardboards, all in English. At the beginning of the 2016-2017 school year, Ms. Ramírez received the first Second Step posters in Spanish that she hung on one of the classroom closet doors. The Spanish version helped shift the Second Step curriculum closer to Latinx students, even if the literal translation is not always completely accurate. I will add an example, as discussed with the teacher, to better explain this point. "Use self-talk" has been translated with "habla contigo mismo," which in English would be closer to the expression "talk to yourself." Also, the literal cultural translation of "talk to yourself" would be considered a sign of mental illness: in Latin American culture, someone who talks to her/himself is considered crazy. Self-talk, in the U.S. culture, commonly refers to the positive and therapeutic act of introspection with oneself to promote self-esteem and contribute toward decision-making. The expression "talk to yourself" in Spanish is less common and does not contain quite the same accuracy in meaning as "use self-talk." Employing the phrase "talk to yourself" in Spanish does not convey the significance held in English. The expressions need to be culturally adapted to the Latinx community, instead of simply translated. In fact, the use of self-talk as a thinking strategy is not as commonly promoted in the Latinx community as it is in the White community.

Latin American cultures live in a more collective and shared dimension. In the song "Latino América" the Puerto Rican band Calle Trece argues "Aquí se comparte, lo mío es tuyo" [Here we share, what is mine is yours]. Sharing is one of the most distinctive characteristics of Latin American culture. Therefore, rather than talking to oneself, a Latinx would share his/her thoughts with someone else, talk it through, and find a solution. It follows that in order to promote the content of the Second Step curriculum, the teacher has to culturally adapt each teaching to her classroom, as she explained in this interview (Table 6): 
Table 6. Teacher's interview about the Second Step Curriculum (audio file 02, transcription section 10, recorded on 22 September 2016).

\begin{tabular}{|c|c|}
\hline Spanish & English Translation \\
\hline $\begin{array}{l}\text { Pero sí, definitivamente tú tienes que conectar el niño } \\
\text { con la vida real, con la que ellos están viviendo. El } \\
\text { currículo no es hecho así. El currículo tiene algo } \\
\text { totalmente diferente. Yo lo hago en español, pero yo } \\
\text { ya esto lo voy a aplicar de una manera distinta. Y lo } \\
\text { importante es esto. Lo importante es eso, es que ellos } \\
\text { puedan alcanzar el objetivo de lo que están viendo de } \\
\text { la clase. }\end{array}$ & $\begin{array}{l}\text { But yes, you definitely have to connect the child with } \\
\text { the real life in which they are living. This curriculum } \\
\text { is not done like this. This curriculum has something } \\
\text { totally different. I do it in Spanish, but I'm going to } \\
\text { apply it in a different way. And the important thing is } \\
\text { this. The important thing is that they can reach the } \\
\text { goal of what they are seeing in the classroom. }\end{array}$ \\
\hline
\end{tabular}

One example, of how Ms. Ramírez connected the Second Step curriculum to the students' own experiences is the ice-breaking activity she used during the second unit that focused on empathy (Table 7). The unit suggested following four stages: (a) students learn to identify and understand their own and other's feelings, (b) students take other's perspectives, (c) students develop compassion for others, and (d) students develop friendship skills to get along better with others (Classroom materials, file 01, PDF, Third grade Second Step Curriculum, p. 11). After considering this unit description, Ms. Ramírez decided to proceed with the activity described in the field note below (Table 7).

Table 7. Field notes, Week 08, 31 October-4 November 2016.

\begin{tabular}{|c|c|}
\hline Spanish-English & English Translation \\
\hline $\begin{array}{l}\text { [Second step curriculum: Identifying other } \\
\text { people's feelings.] }\end{array}$ & $\begin{array}{l}\text { [Second step curriculum: Identifying other } \\
\text { people's feelings.] }\end{array}$ \\
\hline $\begin{array}{l}\text { Ms. Ramírez: el objetivo de hoy es aprender la } \\
\text { palabra empatía. Es cuando alguien está pasando por } \\
\text { un momento difícil o esta triste y ustedes hacen algo } \\
\text { para ayudarlo. Ustedes no van a estar allí solo a } \\
\text { mirarlo ustedes los ayudan. ¿Alguien quiere } \\
\text { compartir algo que le paso en su familia o } \\
\text { sus amigos? }\end{array}$ & $\begin{array}{l}\text { Ms. Ramírez: Today's goal is to learn the word } \\
\text { empathy. It is like when someone is going through a } \\
\text { difficult moment or is sad and you do something to } \\
\text { help him/her. You do not stay there, just looking at } \\
\text { him/her. You help them. Does anyone want to share } \\
\text { something that happened to their family or friends? }\end{array}$ \\
\hline $\begin{array}{l}\text { Fernando: Una vez mi familia y yo fuimos a KMart a } \\
\text { comprar algo de la máquina y mi mama se deslizo en } \\
\text { el agua y se golpeó. Y mi papá la ayudó y la llevó } \\
\text { para la casa. }\end{array}$ & $\begin{array}{l}\text { Fernando: Once my family and I went to Kmart to } \\
\text { buy something for our car and my mom slipped in } \\
\text { the water and bumped her head and hit herself. And } \\
\text { my dad helped her and took her home. }\end{array}$ \\
\hline $\begin{array}{l}\text { Jacob: Una vez mi mama en la casa se cayó y se } \\
\text { golpeó la cabeza y yo llame el } 911 .\end{array}$ & $\begin{array}{l}\text { Jacob: Once my mom fell down and hit her ahead } \\
\text { and I called } 911 .\end{array}$ \\
\hline $\begin{array}{l}\text { Ms. Ramírez: ¡Wow! ¿Tú llamaste el 911? ¿Y qué } \\
\text { le dijiste? }\end{array}$ & $\begin{array}{l}\text { Ms. Ramírez: Wow! Did you call 911? And what did } \\
\text { you say? }\end{array}$ \\
\hline $\begin{array}{l}\text { Jacob: Que mi mama estaba en el piso y se cayó y } \\
\text { necesitaba ayuda. }\end{array}$ & $\begin{array}{l}\text { Jacob: That my mom was on the floor and fell and } \\
\text { needed some help. }\end{array}$ \\
\hline $\begin{array}{l}\text { Ms. Ramírez: Esto es importante. Cuando pasa algo } \\
\text { así, ustedes tienen que llamar el } 911 \text {, pero solo } \\
\text { por emergencias. }\end{array}$ & $\begin{array}{l}\text { Ms. Ramírez: This is important. When something like } \\
\text { that happens, you have to call 911, but only } \\
\text { for emergencies. }\end{array}$ \\
\hline [All students share experiences.] & [All students share experiences.] \\
\hline
\end{tabular}

Ms. Ramírez often engaged in classroom conversations through a dialogical approach with her students. The open dialogue with her class is the instructional strategy that Ms. Ramírez used to interculturally mediate content, elicit student participation, and facilitate the learning process. She recognizes the relationship between language and culture with the intent to develop such understanding in her students. The Second Step program has the potential to offer Latinx students 
those hidden parts of the curriculum that can contribute to closing the opportunity gap with access to problem-solving strategies that can be applied to different academic situations and social life events. In addition, the proper linguistic and cultural adaptation that Ms. Ramírez developed for her classroom has the potential to integrate and expand the complex transnational civic identity that these third-grade emergent bilinguals are developing. The modality in which problem-solving and issues de-escalation is presented in the Second Step proceeds from a typical White U.S. cultural context and leads to the development of a particular civic identity where citizens are individuals who contribute to the public wellness. Through Ms. Ramírez's adaptation, this individualistic civic idea is translated and shaped into a more collective and shared dimension in which the transnational community of students live and develop in this northeast microcosm of the U.S. Once again, it is the dual language teacher's responsibility to adapt the curriculum so that it can become accessible to marginalized groups and nurture their transnational civic identities. Changing the dominant and distorted view of this type of curriculum could function as a clear signal to stop perpetuating the exclusion of marginalized identities.

\section{Discussion}

In the results section, we documented how during our 10-week ethnographic study, Ms. Ramírez and her students reflected on the languages they speak and the places they belong to as means to understand their evolving identities. We focused on the relations between identity, sense of belonging, transnationalism, and language practices. We documented, through three representative data sections, how DLI programs offer multiple opportunities for Latinx students to fully develop as transnational citizens in the U.S. At the same time, we documented how some features of this program's articulation, which definitely separated English and Spanish instruction, may limit the development of a dynamic bilingualism and constrain the possibilities offered to the students.

Research shows [18,88-92] that students enrolled in DLI programs are "capable of achieving as well as, and in some cases better than, non-immersion peers on standardized measures of reading and math" [18] (p. 1). Nevertheless, such results are connected to the way DLI programs are organized and instruction is executed. The disconnection between Spanish and English may create an unequal expectation on linguistic capital [93] and self-contain the development of bilingual and bicultural identities, as demonstrated through the examples we reported in the findings section. Our reflections on this strict separation of languages brought us to reconsider the program's articulation in a way that we did not anticipate at the beginning of the study.

Bilingual education programs can provide emergent bilinguals with the basic infrastructure on which they can truly accomplish academic achievement, bilingualism, biliteracy, and develop cross-cultural competencies. These goals cannot be obtained without a profound consideration of the students' hybrid and fluid identities. Use of Spanish as the language of instruction supports Latinx students' language development and connects them with their heritage cultures. This is only the starting point for considering the multiple assets children of immigrants bring to social studies and transnational civic education. One potential benefit educators should strive to cultivate in immigrant children is an open disposition to diversity, which develops from an understanding of the hybrid and fluid identities of students and teachers.

While engaging with the teacher and the students, we came across multiple examples of how the program structure could inevitably influence the identity development process in ways that we did not anticipate at the beginning of the study and brought us to question some assumptions of bilingual models [64]. On one hand, separating spaces for languages practices encourages students to communicate in one specific language. On the other hand, it represents a contradiction of many students' personal experiences, where languages are bridged in the same context. The use of multiple languages in the same classroom is seen as problematic instead of being considered a resource that can be systematically used through translanguaging strategies and the development of third spaces. 
In this perspective, DLI programs should not be just an instrument to facilitate Latinx students in their acquisition of English, but rather a twofold opportunity for Latinx students to nurture their community language and culture, and for English speaking students to embrace that community and develop a sense of belonging and membership through language. DLI programs can become a counter-hegemonic instrument because of the potential to dismantle power relations based on race and socioeconomic status among other elements. The use of Spanish as the language of instruction is not enough to develop a suitable DLI program. Students need culturally sustaining practices that allow all to engage in conversations, where marginalized groups can have their voices heard and students from dominant groups can advocate for a more equal distribution of resources. This sense of inclusion increases the quality of democratic, transnational civic education and provides important anchors to content in areas of civics, history, economics, and geography.

For example, providing a Spanish translation of the Second Step curriculum does not automatically provide a valid culturally sustaining model to develop transnational citizens. Without Ms. Ramírez's intercultural mediation, the Second Step curriculum risks re-inscribing White, middle class values on Latinx students like many other traditional social studies curricula have done in the past. Ms. Ramírez's recognition of the relationship between language, the contents of the Second Step curriculum, and her adaptation can lead to important considerations in terms of bilingual teacher preparation.

Cognizant of the new sociopolitical climate when this research was conducted, multiple issues of power that linked old and new generations of immigrants were examined. For this reason, the researchers explored the hybrid and fluid identity development of Latinx students in DLI settings from a clearly-stated epistemological lens [36] while trying to increase inclusion and enact counter-hegemonic narratives and transnational civic education. If the Latinx students in this study understood that their identities proceed from their sense of belonging and language practices, they would have probably been more inclined to consider the fundamental roles that belonging and language represent for all individuals. In this way, they could embrace inclusion and avoid reproducing colonizer privilege toward other minorities.

Student identities formed through their understanding of different aspects of culture. The DLI classroom provided the context in which to explore language and these aspects of culture. As students examined and shared their experiences and artifacts of their cultures, they developed what we are interpreting as a transnational civic culture that places identity, belonging, and community as central components in the curriculum. The dialogical approach of the teacher emphasized her creation of a third space where students could share their identities and discuss issues relevant to communities ranging from the local to the global to the glocal. In their study involving secondary students discussing human rights and global issues, Myers and Zaman [94] found that student positionality was a central component when examining different perspectives on these issues. In addition, they write that their findings "suggest that one-size-fits-all civic education programs that concentrate primarily on national patriotism may push away linguistically and culturally diverse youth" (p. 2618). For these reasons, we encourage more studies of DLI programs and their potential to facilitate or encourage the development of transnational civic education curricula.

Traditional civics education that is grounded only in national identity denies a range of identities and perspectives. This has deep implications as they relate to the nature of our democratic communities. How democratic can they be when members of the community are excluded from conversations that determine the future of each member of the community? Although limited due to the fact that we examined a specific DLI program, Ms. Ramírez provided an illustration of a third space where the complexity of different identities and scales of community were expressed against the backdrop of social issues and social justice. This is why we interpret her curriculum as promoting the conditions for transnational civic education.

Imagining a new space, a third-space [63], for transnational civic education, could provide the opportunity for students and teachers to co-construct their fluid and hybrid identities and approach languages and cultures with learning as a holistic dimension. As "an act of communication between 
the I and the You" [50] (p. 20), the physical and metaphorical boundaries between languages, cultures, and geographical locations can be re-imagined, leading to a sense of belonging that affirms the right of Latinx students to exist in their glocal communities.

\section{Conclusions}

The main goal of this study was to expand our knowledge and understanding of policies and practices in DLI elementary schools as a method to advocate for linguistically and culturally diverse learning environments where transnational civic identities are encouraged. Rapidly changing demographics of U.S. schools demand a deeper reflection on the contents and instructional practices that aim to develop hybrid and fluid identities in social studies education and DLI settings. Senses of belonging and language practices are essential components of children's identities and should be considered as such in the implementation of future school policies. The results of this study contribute to the expanding field of identity development in early elementary DLI settings in terms of knowledge, policy, and practices.

First, this study increases our knowledge of students' multiple identities development in DLI settings. An abundance of prior research has described the relationship between English and Spanish language alongside its effects on proficiency and identity formation. Yet the interrelationship between the sense of belonging and language practices as part of imagined communities in DLI early grades has not been addressed from a clearly stated epistemological perspective. As a result, it has not received much attention in the literature.

Second, a heightened knowledge of the complexity of students' multiple identities can impact policy implementation in elementary schools. In particular, we refer to the necessity of linking the consideration of places and belonging as strictly connected with two-way DLI programs in local communities. This study advocates for a change in both policy and public opinion. It calls for educators to share responsibility on two fronts; teachers should offer children the opportunity to develop strong academic-oriented identities while educators must work with colleagues, community members, and institutions to promote diversity while examining dominant discourses that function to marginalize students.

Though this study is based on Spanish language instruction and Latinx culture, some implications can be transferred to less commonly taught languages in bilingual programs, with appropriate considerations concerning the characteristics of the local heritage community. DLI curricula play out in the everyday practices of teachers and students in schools. Here, there exists potential to provide suggestions and recommendations for broadening the curricular and pedagogical practices for teacher preparation and educators of bilingual learners. Multiple questions remain in our mind, and the implementation of a longitudinal study may yet contribute answers to some of these questions.

At the beginning of our study we asked: What would our experience, in Italy for the first author and in the U.S. for the second author, be if we learned the multiple meanings of places, transnationalism, and languages in the social studies curriculum when we were children? Would we look at the world through different lenses if our respective societies had offered a broader range of multicultural possibilities and recognition at the onset of elementary education? With these questions in mind, we explored the experiences of third graders. We found that students became familiar with the concept of hybrid and fluid identity and began to observe themselves and their peers from more inclusive perspectives that indicated a transnational civic culture. A sense of fluid identity was more likely to develop for those students whose first language was Spanish, represented by $73 \%$ of the participants. However, it clearly emerged that some students from predominantly White and English-speaking communities engaged in complex identity development as well, considering the Spanish language and experiences built in the Latinx community as an integral part of their identity. This serves as a step toward more equitable learning environments. This path of recognition that they have begun in the earlier elementary grades could offer them a broader range of multicultural possibilities similar to those that impacted our adult life but were missing in our childhood. This has 
the possibility of being a foundation for a social studies curriculum that encourages transnational civic culture and understanding.

Author Contributions: The authors conceived and designed the study. M.D.S. performed the research, analyzed the data, and wrote the initial report. S.C. substantially contributed to the IRB proposal and manuscript draft; M.D.S. and S.C. wrote the paper and reviewed the paper according to the reviewers' suggestions.

Funding: This research received no external funding.

Acknowledgments: We would like to acknowledge the teacher and the students who participated in the study, as well as the school district and the city, for welcoming the first author and allowing the research team to learn from them. We thank the anonymous reviewers for their careful reading of our manuscript and their many insightful comments and suggestions.

Conflicts of Interest: The authors declare no conflict of interest.

\section{References}

1. Yoder, P.J.; Kibler, A.; van Hover, S. Instruction for English language learners in the social studies classroom: A meta-analysis. Soc. Stud. Res. Pract. 2016, 11, 20-39.

2. Di Stefano, M. Understanding How Emergent Bilinguals Bridge Belonging and Languages in Dual Language Immersion Settings. Ph.D. Thesis, Utah State University, Logan, UT, USA, 2017.

3. Camicia, S.P.; Di Stefano, M. Positionality and Glocal Encounters in Social Studies Teacher Education. In Promoting Global Competence \& Social Justice in Teacher Education; Schwarzer, D., Bridglall, B., Eds.; Lexington Books: Lanham, MD, USA, 2015; pp. 279-297. ISBN 9781498504355.

4. Kymlicka, W. Forward. In Citizenship Education and Global Migration: Implications for Theory, Research, and Teaching; Banks, J.A., Ed.; American Educational Research Association: Washington, DC, USA, 2017; pp. xix-xxv.

5. Paris, D. Culturally sustaining pedagogy: A needed change in stance, terminology, and practice. Educ. Res. 2012, 41, 93-97. [CrossRef]

6. Bashir, B. Beyond state inclusion: On the normalizing and integrating forces of deterritorialized citizenship and civic education. In Citizenship Education and Global Migration: Implications for Theory, Research, and Teaching; Banks, J.A., Ed.; American Educational Research Association: Washington, DC, USA, 2017; pp. 23-39.

7. Harry, B.; Klingner, J. Discarding the deficit model. Educ. Leadersh. 2007, 64, 16-21.

8. An, S. Asian Americans in American History: An AsianCrit perspective on Asian American inclusion in state U.S. history curriculum standards. Theory Res. Soc. Educ. 2016, 44, 244-276. [CrossRef]

9. Brown, K.D.; Brown, A.L. Silenced memories: An examination of the sociocultural knowledge on race and racial violence in official school curriculum. Equity Excell. Educ. 2010, 43, 139-154. [CrossRef]

10. Journell, $\mathrm{W}$. When oppression and liberation are the only choices: The representation of African Americans within state social studies standards. J. Soc. Stud. Res. 2008, 32, 40-50.

11. Shear, S.B.; Knowles, R.T.; Soden, G.J.; Castro, A.J. Manifesting destiny: Re/presenting of indigenous peoples in K-12 U.S. history standards. Theory Res. Soc. Educ. 2015, 43, 68-101. [CrossRef]

12. Woyshner, C.; Schocker, J.B. Cultural parallax and content analysis: Images of Black women in high school history textbooks. Theory Res. Soc. Educ. 2015, 43, 441-468. [CrossRef]

13. Camicia, S.P. Critical Democratic Education and LGBTQ-Inclusive Curriculum: Opportunities and Constraints; Routledge: New York, NY, USA, 2016.

14. Department of Education, Office of English Language Acquisition. Dual Language Education Programs: Current State Policies and Practices; American Institutes for Research: Washington, DC, USA, 2015; Available online: http:/ / www.air.org/sites/default/files/downloads/report/Duallanguage-Education-ProgramsCurrent-State-Policies-April-2015.pdf (accessed on 8 June 2018).

15. Goldenberg, C.; Wagner, K. Bilingual Education. Reviving an American Tradition. Am. Educ. 2015, 39, $28-44$.

16. Spicer-Escalante, M.L. Introduction to dual language immersion: Utah's experience. In Perspectives on Effective Teaching in Dual-Language Immersion and Foreign Language Classrooms; de Jonge-Kannan, K., Spicer-Escalante, M.L., Abell, E.I., Salgado, A.J., Eds.; Communication Studies at Utah State University: Logan, UT, USA, 2017; pp. 3-15. 
17. Howard, E.R.; Lindholm-Leary, K.J.; Rogers, D.; Olague, N.; Medina, J.; Kennedy, D.; Sugarman, J.; Christian, D. Guiding Principles for Dual Language Education, 3rd ed.; Center for Applied Linguistics: Washington, DC, USA, 2018; ISBN 9780872811300.

18. Fortune, T. What the Research Says About Immersion. Chinese Language Learning in the Early Grades: A Handbook of Resources and Best Practices. pp. 9-13. Available online: http://asiasociety.org/files/chineseearlylanguage.pdf (accessed on 8 June 2018).

19. Spicer-Escalante, M.L.; Wade, O.; Leite, J. It takes a village to raise multilingual-multicultural children: The story of Utah dual language immersion. Presented at the 44th National Association of Bilingual Education, Las Vegas, NE, USA, 5-7 March 2015.

20. DeNisco, A. Hmong Dual Language Programs Preserve Culture. District Admin. 2015, 51. Available online: https:/ / www.districtadministration.com/article/hmong-dual-language-programs-preserve-culture (accessed on 8 June 2018).

21. Lee, J.; Hill-Bonnet, L.; Illispie, J. Learning in two languages: Interactional spaces for becoming bilingual speakers. Int. J. Biling. Educ. Biling. 2008, 11, 75-94. [CrossRef]

22. Lee, J.; Hill-Bonnet, L.; Raley, J. Examining the effects of language Brokering on student identities and learning opportunities in dual immersion classrooms. J. Lang. Identity Educ. 2011, 10, 306-326. [CrossRef]

23. Lee, J.; Jeong, E. Korean-English dual language immersion: Perspectives of students, parents and teachers. Lang. Cult. Curric. 2013, 26, 89-107. [CrossRef]

24. López-Robertson, J.; Schramm-Pate, S.S. (Un)official knowledge and identity: An emerging bilingual's journey into hybridity. Innov. Lang. Learn. Teach. 2013, 7, 40-56. [CrossRef]

25. Palmer, D. A dual immersion strand Program in California: Carrying out the promise of dual language education in an English-dominant context. Int. J. Biling. Educ. Biling. 2007, 10, 752-768. [CrossRef]

26. Potowski, K. Student Spanish use and investment in a dual immersion classroom: Implications for second language acquisition and heritage language maintenance. Mod. Lang. J. 2004, 88, 75-101. [CrossRef]

27. Potowski, K. Language and Identity in a Dual Immersion School; Multilingual Matters: Clevedon, UK, 2007.

28. Palmer, D. Race, power, and equity in a multiethnic urban elementary school with a dual language "strand" program. Anthropol. Educ. Q. 2010, 41, 94-114. [CrossRef]

29. Palmer, D. Building and destroying students' 'academic identities': The power of discourse in a two-way immersion classroom. Int. J. Qual. Stud. Educ. 2008, 21, 647-667. [CrossRef]

30. Bassetti, B.; Nicoladis, E. Research on grammatical gender and thought in early and emergent bilinguals. Int. J. Biling. 2016, 20, 3-16. [CrossRef]

31. Burke, A.; Morita-Mullaney, T.; Singh, M. Indiana emergent bilingual student time to reclassification: A survival analysis. Am. Educ. Res. J. 2016, 53, 1310-1342. [CrossRef]

32. Hickey, P.J. "They always keep us in line": Neoliberalism and elementary emergent bilinguals. J. Crit. Educ. Policy Stud. 2016, 14, 14-40.

33. Morrison, P. School home interactive curriculum development: Teachers and families in partnership. In Handbook of Research on Effective Communication in Culturally Diverse Classrooms; Gonzalez, K., Frumkin, R., Eds.; IGI Global: Hershey, PA, USA, 2016.

34. Kim, J.I.; Viesca, K.M. Three reading-intervention teachers' identity positioning and practices to motivate and engage emergent bilinguals in an urban middle school. Teach. Teach. Educ. 2016, 55, 122-132. [CrossRef]

35. Gándara, P. Educating Immigrant Students and Emergent Bilinguals (in an Anti-Immigrant Era). Presented at the American Education Research Association Centennial Lecture Series, Brooklyn, NY, USA, 30 November 2016.

36. Paris, D.; Alim, H.S. What are we seeking to sustain through culturally sustaining pedagogy? A loving critique forward. Harv. Educ. Rev. 2014, 84, 85-100. [CrossRef]

37. Ladson-Billings, G. What we can learn from multicultural education research. Educ. Leadersh. 1994, 51, $22-26$.

38. Ladson-Billings, G. Culturally relevant pedagogy 2.0: Aka the remix. Harv. Educ. Rev. 2014, 84, 74-84. [CrossRef]

39. Tochon, F.V. When authentic experiences are "enminded" into disciplinary genres: Crossing biographic and situated knowledge. Learn. Instr. 2000, 10, 331-359. [CrossRef]

40. Shinew, D. Citizenship and belonging: Constructing "a sense of place and a place that makes sense." In Social Studies-The Next Generation; Segall, A., Heilman, E.E., Cherryholmes, C.H., Eds.; Peter Lang Publishing: New York, NY, USA, 2006; pp. 77-93. 
41. Pennycook, A. Language as a Local Practice; Routledge: London, UK, 2010.

42. Anderson, B. Imagined Communities; Verso: London, UK; New York, NY, USA, 1991/2006.

43. Jaffee, A.T. Social studies pedagogy for Latino/a newcomer youth: Toward a theory of culturally and linguistically relevant citizenship education. Theory Res. Soc. Educ. 2016, 44, 147-183. [CrossRef]

44. Ladson-Billings, G. Toward a theory of culturally relevant pedagogy. Am. Educ. Res. J. 1995, 32, 465-491. [CrossRef]

45. Paris, D.; Alim, H.S. Culturally Sustaining Pedagogies: Teaching and Learning for Justice in a Changing World; Teachers College Press: New York, NY, USA, 2017.

46. DeJaeghere, J. Intercultural and global meanings of citizenship education in the Australian secondary curriculum: Between critical contestations and minimal construction. In Reimagining Civic Education: How Diverse Societies Form Democratic Citizens; Stevick, D., Levinson, B., Eds.; Rowman and Littlefield: Lanham, MD, USA, 2007; pp. 293-316.

47. Freire, P. Pedagogy of the Oppressed; Herder and Herder: New York, NY, USA, 1970.

48. Vickery, A.E. "I worry about my community": African American women utilizing communal notions of citizenship in the social studies classroom. Int. J. Multicult. Educ. 2016, 18, 22-44. [CrossRef]

49. Bhabha, H.K. Nation and Narration; Routledge: New York, NY, USA, 1990.

50. Bhabha, H.K. The Location of Culture; Routledge: New York, NY, USA, 1994.

51. Chuang, R. Theoretical perspectives: Fluidity and complexity of cultural and ethnic identity. In Communicating Ethnic Cultural Identity; Fong, M., Chuang, R., Eds.; Rowman and Littlefield: Lanham, MD, USA, 2004; pp. 51-68.

52. Grossberg, L. Identity and cultural Studies: Is that all there is? In Questions of Cultural Identity; Hall, S., du Gay, P., Eds.; Sage Publications: London, UK, 1996; pp. 88-107.

53. Hall, S. Cultural identity and diaspora. In Identity: Community, Culture, Difference; Rutherford, J., Ed.; Lawrence Wishart: London, UK, 1990; pp. 222-237.

54. Hall, S. Cultural identity and cinematic representation. In Black British Cultural Studies: A Reader; Baker, H.A., Diawara, M., Jr., Lindeborg, R., Eds.; University of Chicago Press: Chicago, IL, USA, 1996; pp. $210-222$.

55. Lemke, J.L. Identity, Development and desire: Critical questions. In Identity Trouble: Critical Discourse and Contested Identities; Caldas-Coulthard, C., Idema, R., Eds.; Palgrave Macmillan: London, UK, 2008; pp. 17-42.

56. McCarthey, S.J.; Moje, E.B. Identity matters. Read. Res. Q. 2002, 37, 228-238. [CrossRef]

57. Nasir, N.S.; Saxe, G.B. Ethnic and academic identities: A cultural practice perspective on emerging tensions and their management in the lives of minority students. Educ. Res. 2003, 32, 14-18. [CrossRef]

58. Rampton, B. Linguistic ethnography and the study of identities. Working Papers in Urban Language Literacies, Paper 43. Presentation at the British Sociological Association Annual Conference, University of East London, London, UK, 3 April 2007; Available online: https:/ /www.kcl.ac.uk/sspp/departments / education/research/research-centres/ldc/publications/workingpapers/the-papers/43.pdf (accessed on 8 June 2018).

59. Lee, J.S.; Anderson, K.T. Negotiating linguistic and cultural identities: Theorizing and constructing opportunities and risks in education. Rev. Res. Educ. 2009, 33, 181-211. [CrossRef]

60. Paris, D. "They're in my culture, they speak the same way": African American language in multiethnic high schools. Harv. Educ. Rev. 2009, 79, 428-448. [CrossRef]

61. Paris, D. "A friend who understand fully": Notes on humanizing research in a multiethnic youth community. Int. J. Q. Stud. Educ. 2011, 24, 137-149. [CrossRef]

62. Domínguez, M.C. Decolonizing Teacher Education: Explorations of Expansive Learning and Culturally Sustaining Pedagogy in a Social Design Experiment. Ph.D. Thesis, University of Colorado, Boulder, CO, USA, 2015.

63. Bhabha, H.K. Cultural Diversity and Cultural Differences. In The Post-Colonial Studies Reader; Ashcroft, B., Griffiths, G., Tiffin, H., Eds.; Routledge: New York, NY, USA, 2006; pp. 155-157.

64. García, O. Education, multilingualism and translanguaging in the 21st century. In Social Justice through Multilingual Education; Skatnabb-Kangas, T., Phillipson, R., Mohanty, A.K., Eds.; Multilingual Matters: Bristol, UK, 2009.

65. Solórzano, D.G.; Yosso, T.J. Critical race methodology: Counter-storytelling as an analytical framework for educational research. Qual. Inquiry 2002, 8, 23-44. [CrossRef] 
66. Salinas, C.; Rodríguez, N.N.; Lewis, B.A. The Tejano History Curriculum Project: Creating a Space for Authoring Tejanas/os into the Social Studies Curriculum. Biling. Res. J. 2015, 38, 172-189. [CrossRef]

67. Castro, A.J. The role of teacher education in preparing teachers for critical multicultural citizenship. J. Soc. Stud. Res. 2014, 38, 189-203. [CrossRef]

68. Delgado Bernal, D.; Alemán, E., Jr.; Garavito, A. Latina/o undergraduate students mentoring Latina/o elementary studnets: A borderlands analysis of shifting identites and first-year experiences. Harv. Educ. Rev. 2009, 79, 560-585. [CrossRef]

69. Salinas, C.S.; Fránquiz, M.E.; Rodríguez, N.N. Writing Latina/o historical narratives: Narratives at the intersection of critical historical inquiry and LatCrit. Urban Rev. 2016, 48, 419-439. [CrossRef]

70. Fránquiz, M.E.; del Carmen Salazar, M.; DeNicolo, C.P. Challenging majoritarian tales: Portraits of bilingual teacher deconstructing deficit views of bilingual learners. Biling. Res. J. 2011, 34, 279-300. [CrossRef]

71. Anzaldúa, G.E. (Un)natural bridges, (Un)safe spaces. In This Bridge We Call Home: Radical Visions for Transformation; Anzaldúa, G.A., Keating, A., Eds.; Routledge: New York, NY, USA, 2002; pp. 1-5.

72. Camicia, S.P.; Bayon, A. Curriculum development collaboration between colonizer and colonized: Contradictions and possibilities for democratic education. In Ethics and International Curriculum Work: The Challenges of Culture and Context; Mason, T.C., Helfenbein, R.J., Eds.; Information Age: Charlotte, NC, USA, 2012; pp. 73-92. ISBN 9781617358463.

73. Bondy, J.M. Latina youth, education, and citizenship: A feminist transnational analysis. Theory Res. Soc. Educ. 2016, 44, 212-243. [CrossRef]

74. Glesne, C. Becoming Qualitative Researchers, 4th ed.; Pearson Education Inc.: Boston, MA, USA, 2011.

75. Gómez, L. Two-way bilingual education: Promoting educational and social change. J. Tex. Assoc. Biling. Educ. 2000, 5, 43-54.

76. Gómez, L.; Freeman, D.; Freeman, Y. Dual language education: A promising 50-50 Model. Biling. Res. J. 2005, 29, 145-164. [CrossRef]

77. Schensul, S.L.; Schensul, J.J.; LeCompte, M.D. Initiating Ethnographic Research: A Mixed Methods Approach; Rowman Littlefield: Lanham, MD, USA, 2013; Volumes 2 and 3.

78. Forsey, M.G. Ethnography as participant listening. Ethnography 2010, 11, 558-572. [CrossRef]

79. Braswell, G.S. Observations of representational practices by Indian-descent children in a U.S. preschool classroom: Connections among people, spaces and artifacts. Early Child. Educ. J. 2015, 43, 135-142. [CrossRef]

80. Fereday, J.; Muir-Cochrane, E. Demonstrating rigor using thematic analysis: A hybrid approach of inductive and deductive coding and theme development. Int. J. Qual. Methods 2006, 5, 1-11. [CrossRef]

81. Crabtree, B.F.; Miller, W.L. Doing Qualitative Research, 2nd ed.; Sage: Thousand Oaks, CA, USA, 1999.

82. Boyatzis, R.E. Transforming Qualitative Information: Thematic Analysis and Code Development; SAGE Publications: Thousand Oaks, CA, USA, 1998.

83. Kasun, G.S.; Saavedra, C.M. Crossing borders toward young transnational lives. In Cross-Cultural Considerations in the Education of Young Immigrant Learners; Keengwe, J., Onchwari, G., Eds.; IGI Global: Hershey, PA, USA, 2013; pp. 201-2017.

84. García-Mateus Palmer, D. Translanguaging Pedagogies for Positive Identities in Two-Way Dual Language Bilingual Education. J. Lang. Identity Educ. 2017, 16, 245-255. [CrossRef]

85. Palmer, D.K.; Martínez, R.A.; Mateus, S.G.; Henderson, K. Reframing the debate on language separation: Toward a vision for translanguaging pedagogies in the dual language classroom. Mod. Lang. J. 2014, 98, 757-772. [CrossRef]

86. Sánchez, M.T.M.; García, O.; Solorza, C. Reframing language allocation policy in dual language bilingual education. Biling. Res. J. 2018, 41,37-55. [CrossRef]

87. Committee for Children. Second Step. Early Learning through Grade 8. Skills for Social and Academic Success, 2017. Available online: http:/ / www.cfchildren.org/secondstep (accessed on 8 June 2018).

88. Genesee, F. Dual language in the global village. In Pathways to Multilingualism: Evolving Perspectives on Immersion Education; Fortune, T.W., Tedick, D.J., Eds.; Multilingual Matters: Clevedon, UK, 2008; pp. $22-45$.

89. Lindholm-Leary, K. Dual Language Education; Multilingual Matters: Clevedon, UK, 2001.

90. Lindholm-Leary, K. Student outcomes in Chinese two-way immersion programs: Language proficiency, academic achievement, and student attitudes. In Immersion Education: Practices, Policies, Possibilities; Tedick, D.J., Christian, D., Fortune, T.W., Eds.; Multilingual Matters: Clevedon, UK, 2011; pp. 81-103. 
91. Turnbull, M.; Lapkin, S.; Hart, D. Grade 3 immersion students' performance in literacy and mathematics: Province-wide results from Ontario (1998-99). Can. Mod. Lang. Rev. 2001, 58, 9-26. [CrossRef]

92. Watzinger-Tharp, J.; Swenson, K.; Mayne, Z. Academic achievement of students in dual language immersion. Int. J. Biling. Educ. Biling. 2016, 19, 1-16. [CrossRef]

93. Bourdieu, P. Language and Symbolic Power; Harvard University Press: Cambridge, MA, USA, 1991.

94. Myers, J.P.; Zaman, H.A. Negotiating the Global and National-Immigrant and Dominant-Culture Adolescents Vocabularies of Citizenship in a Transnational World. Teach. Coll. Rec. 2009, 111, 2589-2625. 